\title{
A Lotmanian Approach to the Ideological Function of Honour in Early Modern English Texts
}

\author{
JESÚS LÓPEZ-PELÁEZ CASELLAS
}

\begin{abstract}
This essay aims at presenting a semiotic study of the ideological function of the concept of honour in early modern prose writing in England. By means of both a critical study of the major axiological and epistemological dimensions of sixteenth and seventeenth century honour, and a cultural semiotic approach to this notion (Lotman's typology of cultures), it is my belief that it will be possible to clarify the social and ideological meaning and function of early modern honour, and to account for the transformations that the concept underwent during this period of transition, especially as can be observed in non-literary works (moral treatises and conduct books, mainly). Additionally, this is also intended to contribute to further study of the form and function of the code and concept of honour in the English literature (drama and poetry) of this period.
\end{abstract}

Keywords: honour, early modern England, Yuri Lotman, typology of cultures, moral treatises, conduct books, Thomas Elyot, Robert Ashley, James Cleland, Lodowicke Bryskett

DOI: http://dx.doi.org/10.12697/IL.2013.18.1.02

\section{The sources of early modern honour}

The origins of the early modern concept of honour, in England and elsewhere in Western Europe, have to be traced as far back as the ninth century B.C. in Ancient Greece. As Werner Jaeger demonstrated in his seminal Paideia (Jaeger 1945: 15-30), the aristocratic society depicted in Homer's narrations produced a heavily ideologized narrative that we will still recognize as 'honour' almost 2500 years later. Indeed, the Ancient Greek term aretē could be considered as the most closely related pre-text of early modern puritan 'virtue' (although, unlike the latter, not restricted to the moral sense) and ultimately as the guiding idea behind early modern honour. Greek aretē is the expression of the highest knightly ideal, and it includes the related notions of refined conduct and military heroism (Jaeger 1945: 3); in this sense it is also restricted to male 
A Lotmanian Approach to the Ideological Function of Honour in Early Modern English Texts

aristocrats. An honourable conduct, then, meant for the aristocratic warrior of Ancient Greece an attempt, or the expression of an attempt, to achieve areté, with the purpose of being praised by his peers, that is, people of prestige. In short, aretē stressed the importance of external opinion (i.e., it was conferred from outside), it was based on military feats and it was naturally connected with the aristocracy; in general terms, it was from this concept that a more recognizable idea of honour developed thorough the Middle Ages and eventually emerged in the sixteenth century.

Before it turned into our recognizable early modern concept of honour, this term had to undergo important transformations through the medieval period and beyond; namely, it included moral and ethical values, and overflowed its aristocratic origins to become a wider notion (Jaeger 1945: 24). This complex set of meanings, more readily differentiated by moralists of the sixteenth century in Western Europe than by Homer, was known as aidōs in Ancient Greece. The English stock translation of aidos is 'shame', and, to be sure, both terms share certain features: both imply being exposed to the gaze of the other, both may provoke physical reactions (blushes, aggressions), and both are attended by certain patterns of behaviour of a ritualistic kind (averting the gaze, hiding, bowing the head etc...) (Cairns 1993: 1-26). However, and on a psychological level, they are not coextensive: whereas 'shame' in English seems to be related to the negative implications of the disapproval of others and the consequent fear of external sanctions, aidōs is more positively involved in the set of recommendations and constraints that one has to follow in his arrangements with others. Thus, the meanings of the etymologically associated Greek verb aideomai may include: 'I feel shame before', 'I respect' or 'I am abashed'. Aidōs, then, is an aggregate of different meanings that will be retaken later by moralists of the English sixteenth and seventeenth centuries: embarrassment, shame and guilt, honour, and reputation; and, consequently, dishonour, contumelia and the aphilotimon. ${ }^{1}$ This set of concepts, significantly similar to those applied to the expected and prescribed behaviour of the early modern man, can only be covered, although partially, by what I will be calling the early modern 'code/concept of honour'.

Contumelia (Latin) was for the Ancients equivalent to early modern dishonour, and the aphilotimos was the man for whom honour was not a guiding principle: consequently, a dishonoured man. 
LÓPEZ-PELÁEZ CASELLAS

Aristotle is the first advocator of the concept of honour directly influential in the English Renaissance. ${ }^{2}$ As a moralist, he provided arete (so far, as we just saw, a form of amoral virtue) with some axiological (ethical) content; thus, the new Aristotelian virtue, which designates a manly quality and refers primarily to valour and justice, includes intellectual (wisdom, intelligence and prudence) and ethical (liberality and moderation) components. Moral virtues, for Aristotle, are the outcome of habit, and their essential quality is moderation, or mediocrity: a middle state which lies between the vice of excess and the vice of deficiency. In his Eudemian Ethics (fourth c. BC) he postulates that moral virtue has to do with the personal selection of mediocrity (Aristotle 1971: II, 10). This concept (the golden mean) will become a guiding principle of the approaches to honour and virtue by Aristotle, Cicero, Marcus Aurelius and most of our early modern moralists, as we will see. Aristotle defines honour in the Nichomachean Ethics (fourth c. BC) as "the reward of virtue" (Aristotle 1970: I, 5), meaning by virtue a certain habit of moral excellence whose prize is conferred by your peers. In this sense, it is clear from these ideas that since honour is the reward of moral goodness, it must be subordinated to virtue. According to Aristotle, confusion arises from considering honour as equal to happiness, the foundation of virtue, since honour depends on those who bestow it, and this is not appropriated to happiness (Aristotle 1970: I, 5).

Some centuries later, Cicero goes even further in this relation of virtue and honour. He establishes a close link between the "four cardinal virtues" and honour or, in this case, honesty, making honest conduct stem directly from adherence to one of the four virtues (Cicero 1976: II, 20). Cicero's honestas resembles Aristotle's honour in its relation to virtue; in any case, Cicero doesn't seem consistent in his use of this term and will change to 'honour', 'fame' or 'glory' in different contexts. In his elaboration, to be free from vices will also be a prerequisite to be honoured or admired by others (Cicero 1976: II, 10). Likewise, Cicero also accepts and recognizes the importance of a good reputation; he is careful to indicate that it shouldn't be a man's main concern, but at the same time he postulates men's subordination to higher entities, such as country and fellow countrymen. This is certainly one of the first references that clearly implies some kind of ideological appropriation or manipulation in order to inoculate an important degree of conformism with the status quo; the process involved is what some authors have identified as the turning of dangerous

2 I am aware that neither Aristotle's nor Plato's agent-centred moral theories exactly reproduce popular Ancient Greek morality, but to discriminate, at this level, that difference would imply a sophisticated philosophical analysis which is out of the scope of this article. See Annas 1981; see also Irwin 1985. 
A Lotmanian Approach to the Ideological Function of Honour in Early Modern English Texts

(stoic) self-sufficiency into acceptable self-discipline (Chew 1988: 2), or as the consequence of what Mervyn James called "the moralization of politics" in the early modern period (1978: 413). These elements, the inextricable association of honour and virtue and the acceptance of the public, or social, dimension of honour (that is, reputation) is what relates Cicero to Aristotle in a historically ongoing discussion about the evolving notion of honour.

Interestingly, moral philosophy of the early modern period is more closely related to the ethical writing of, basically, Aristotle's Nichomachean Ethics (fourth c. BC) and Cicero's De Officiis (first c. BC) than it is to the medieval thought of Aquinas or Ockham. Apart from those two seminal references, the English moralist of this period used to make frequent allusion to Plato's Republic (fourth c. BC), Aristotle's Rhetoric and - to a lesser extent - his Eudemian Ethics, Cicero's De Finibus Bonorum et Malorum, Marcus Aurelius' Meditations (second c.), Seneca's Moral Essays and Moral Epistles (first c.), Epictetus' Encheiridion (first-second c.), and finally, as any reader of Shakespeare knows, Plutarch's Lives (first c.). The enormous influence of these works during the English early modern period, not always read directly but mediated through the translation, and frequently the interpretation and even editing of other authors (as was very famously the case with Plutarch), can be easily found in a number of well-known early modern treatises, such as Thomas Elyot's The Boke Named the Gouernor (1531), a seminal moral essay which was clearly (and admittedly) following Aristotle and Cicero; or Antonio de Guevara's Diall of Princes (1529), a compilation of moral teachings mostly lifted from the Meditations of Marcus Aurelius ${ }^{3}$.

Other essayists of the period, directly indebted to classical definitions of ethics and morality, include Count Romei's The Courtier's Academie (1598), Lodowycke Bryskett's A Discourse of Civill Life (1606), and John Cleland's The Institution of a Young Nobleman (1607). This concern with moral behaviour, combined with a similar reliance on classical sources, produced a sustained interest in the allegedly single most influential and complex code of conduct of the whole early modern period, namely, the concept of honour. Consequently, several treatises and pamphlets by various scholars tried to guide the Tudor and Jacobean subject between the Scylla and Charybdis of an excessive and defective concern with reputation, fame, glory and the many different forms that honour adopted. Thus, works such as William Segar's The Booke of Honor and Armes (1590), John Norden's The Mirror of Honor (1597), Thomas Milles' The Catalogue of Honour (1610), Gervase Markham's Honour in his Perfection

3 Originally published in Spanish in 1529, it was translated into English by Thomas North in 1557. 
LÓPEZ-PELÁEZ CASELLAS

(1624), Francis Markham's The Booke of Honour (1625), and, above all, the Aristotelian Robert Ashley's Of honour (1600), all of them testify, in their own various ways, to a sustained concern with honour as a code of conduct heavily influencing not only the writing of the period (from Sidney's Arcadia to Shakespeare's Othello) but also the life and politics of the Tudor and Stuart eras (from the Pilgrimage of Grace or Sidney's death at Zutphen to Puritan derogatory depictions of Cavaliers as the epitome of vainglory).

\section{Lotman and the typology of culture}

The Russian-Estonian semiotician Yuri Lotman put, in the 1970s, the basis for a theory of culture which, although, to a certain extent, remained unfinished, was part of a wider cultural semiotic paradigm that, later - in the 1980s and early 1990s -, would develop into Lotman's related theories of the semiosphere and of culture as explosion. ${ }^{4}$ In Stat'i po tipologii kul'tury (The Problem of Sign and of Sign Systems in the Typology of Russian Culture before the Twentieth Century $)^{5}$ Lotman identified four different modes of culture which, he suggested, characterize four historical and cultural periods: the Middle Ages, the Renaissance, the Enlightenment, and Romanticism. These periods, Lotman claimed, work semiotically as cultural artifacts, or 'sign systems', which for Lotman means that they can be semiotically defined through the functions performed by signs (linguistic and otherwise) in the symbolic construction of reality operated by them. The four different cultural modes, or historical and cultural periods, that he describes through this theory are then characterized both synchronically and diachronically as the product of the combination of the paradigmatic - or symbolic - and syntagmatic - or relational - dimensions of the sign. Given that for Lotman language is the primary modelling system of a culture, it is not surprising that this theory puts the sign, especially in its linguistic function, at the centre of his typology of culture; however, he does not dismiss the influence of secondary modelling systems (like literature or painting) in the characterization of these periods.

4 For an approach in English to some of his most relevant work, see On the Semiotic Mechanism of Culture (1978), The Text within the Text (1994), and Universe of the Mind (2001). However, Lotman's work, originally published in Russian and Estonian, is almost fully translated into Italian and Spanish. See the collection La semiosfera (in three volumes), edited by Lotmanian scholar and translator Desiderio Navarro.

5 I will be following the Spanish translation by N. Méndez: "El problema del signo y del sistema sígnico en la tipología de la cultura anterior al siglo XX”. 
A Lotmanian Approach to the Ideological Function of Honour in Early Modern English Texts

As we have suggested above, and according to his approach, the whole system revolves around the basic functioning of the sign, which could be described as metaphoric and metonymic, or - as already mentioned - paradigmatic and syntagmatic. The former deals with the referential or symbolic (substituting) function of the sign, what it represents or stands for, in a similar way to how metaphors work in literary writing. Anglo-Saxon medieval poetry was based on a symbolic, paradigmatic, mode of culture, as the metaphoric use of kenning suggests, or as the various symbols structuring poems such as The Dream of the Rood (seventh-eighth c.) or The Wanderer (eighth-ninth c.) show; Chaucer's opening of the General Prologue to the Canterbury Tales (ca. 1380), with its explicit allusion to the connections between the renewal of life in Spring and the renewal of the soul through the pilgrimage, is another clear example of this. The second function is the relational, or syntagmatic, one, and it is based on the relationships that the sign establishes with other signs, its syntagmatic (relational) connections. A part-for-the-whole relationship, of a metonymic kind, is the one that most clearly exemplifies this kind of sign function, and we clearly find it in the so-called 'absent presence/present absence of the lady' of the Elizabethan sonnet.

From a diachronic perspective, through the combination of these two functions - the paradigmatic and the syntagmatic ones - Lotman produces four different modes of culture, depending on these four possibilities: the absence of the two functions, the presence of both, or the alternate absence and presence of one and the other. Thus, Lotman characterizes the medieval period as one in which only the paradigmatic function is present, and consequently he describes it as building a symbolic model of the world, whereas the early modern period, the one in which the relational function is central, projects a syntagmatic one. Lotman's model is not at all a fixed, static or harmonious one, since the dynamics of the codes, and the contrast between the set of codes belonging to text and reader, prevents such kind of stasis; besides, texts in his typology of culture appear as composite, complex and full of contradiction, issues which through his theory can be appropriately addressed.

However, in some cases it could be argued that Lotman did not develop in full detail what the nature of the relations between these two models, paradigmatic and syntagmatic, in the moment of transition from one period to the next, was, and - more to the point - Lotman's model may appear at times to rely too heavily on a somewhat static view of history, one in which different periods occasionally seem to be characterized by one single and relatively unconflictive mode of culture. In this sense Raymond Williams' own formulation about culture as a constant negotiation between residual, emergent and dominant forms appears to be helpful in order to overcome that shortcoming, helping 
LÓPEZ-PELÁEZ CASELLAS

to envisage this relation as one of conflict between the residual medieval-symbolic and the emergent early modern-paradigmatic modes, with the transition itself as the dominant mode in the late sixteenth and early seventeenth centuries (Williams 1977: 121-27; 1980: 35-45). ${ }^{6}$ Williams, then, completes Lotman's model by providing a perception of each period - while characterized by a specific sign system and the absence of another - as full of contradictory relationships in the interplay of his three forms of culture. Lotman's typology of cultures, complemented with Williams', seems to provide a solid basis to analyze the functioning of honour, and the clash of epistemic and ideological models that conditioned its development during the early modern period.

\section{Honour in the early modern period}

Honour in sixteenth and seventeenth century England functioned as one form of symbolic production of meaning and value, in much the same way as money, in its different forms (coins, plate money, paper money), did. According to Lotman, and as we just saw, we witness a transition from a medieval (symbolic and paradigmatic) model to an early modern (relational, syntagmatic) one; if the former is based on the belief in the essence of things, the latter relies on the value of change, which is evidently relational. In Max Weber's classic formulation, the medieval episteme is based on the reciprocity nexus, which entails among other things a lack of political centrality and the legitimation of history by reference to a higher, transcendent, reality. ${ }^{7}$ In Lotman's words:

The importance of the sign lay in its substitution function: the substituted element was considered as content and the substituting element as expression. For this reason the substituting element could never have an autonomous value: it acquired value according to the hierarchic position of its content in the general model of the world. (Quoted in Serpieri 1991: 125)

\footnotetext{
6 To my knowledge, the two authors who have most brilliantly applied these theories to the study of early modern texts have been Alessandro Serpieri and Giuseppina Restivo. See Serpieri's Reading the Signs: Towards a Semiotics of Shakespearean Drama (Serpieri 1991, translated by K. Elam from the Italian), and Restivo's Shakespeare between Machiavelli and Montaigne: An Exploration Through Lotman's Codes (Restivo 1996). Both Italian academics deal with a Lotmanian approach to Shakespeare's drama.

7 Ben R. Schneider has developed these ideas, in connection with the neo-Stoic revival of the early modern period, in a number of texts. See his Shakespeare's Morals.
} 
A Lotmanian Approach to the Ideological Function of Honour in Early Modern English Texts

On the other hand, the centripetal energy of the paradigmatic model, appearing in the Renaissance and the early modern period, contributes to a centralization of power, delegitimizes most teleological explanations of reality and introduces the economic and material nexus as the foundation of human relations. This means that meaning will be relative, and made dependent on the relations established among individuals, ideas and objects. For Lotman, "The meaning of a man or of a phenomenon was determined not by its relationship with their essences at another level but by its insertion into a given level" (ib.). This transformation is eventually based on the ideological and material (economic mainly) changes taking place in England or Spain, and which were described some decades ago by, for instance, Christopher Hill (1965) and Juan Carlos Rodríguez (1990).

The change of paradigm that Lotman's model suggests has many deep and complex consequences for the notion of honour. Medieval theories of analogy attended to the nature of the relations between concepts and words employed, and of these, the so-called analogy of imitation "appealed to a relation of likeness between God and creatures. Creatures are called good or just because their goodness or justice imitates or reflects the goodness or justice of God" (SEP 2012). Indeed, according to Lotman's typology of culture, during the Middle Ages "the world of history received its legitimation from its correspondence to the eternal world of symbolic reality" (Restivo 1996: 45). This constant dependence on a higher level of reality characterized late medieval honour: no fixed loyalty to 'earthly' superiors existed, and this meant the predominance of competitive assertiveness and a strong emphasis on the man of honour's autonomy, which prevented unconditional obedience and, evidently, produced dissidence. Significantly, this medieval cultural episteme fostered two central features of medieval honour, namely 'prowesse' and steadfastness: the former, from Anglo-Norman pruesce, according to the Oxford English Dictionary was "[a]n act of bravery; a valiant deed; a daring feat or exploit", and also "[v]alour, bravery, gallantry, martial daring; manly courage, fortitude.” Evidently no intellectual value was involved, and only secondarily we can find an ethical component. The latter, steadfastness, focused exclusively on the spirit with which events were encountered, not on the success or failure of the actions undertaken. In other words, paradigmatic or symbolic relations involve the constant appeal to a higher validating entity, and this implies that honour does not establish any meaningful relation with, or submit to, any other earthly authority, as it is self-validating, autonomous and 'radically' (in the double meaning of 'going to the root' and 'subversively') independent. It is against this spirit of autonomy verging on dissidence and against this unawareness of the existence of any form of central authority to which individuals should be subordinated, that 
we may contrast the emergent early modern cultural mode, which will produce a syntagmatic type of honour.

The first consequence of this clash of epistemological values involving the nature and meaning of honour can be found in connection with the origins, or sources, of honour. Medieval symbolic honour was based, like Greek and Roman honour, on lineage, or blood, which all through the medieval and early modern periods was a powerful signifier. This version of honour, 'honour by nature', was sustained through writings by Raymond Lull's Book of the Order of Chivalry (1276, translated into English in 1484), in which he writes about "noblesse of heart"; or more specifically by the Book of Saint Albans (1486), a treatise that, while dealing with the life of a gentleman (focusing on his pastimes: hunting or hawking), introduced an elaborate reflection on gentility, which could be 'of blood' and 'granted'. On the other hand, early modern writings on honour progressively replace this old medieval sense of honour and lineage with the so-called Bartolan view (after Bartolo de Saxoferrato), an early modern approach to the writings of this Italian lawyer which introduced a meritocratic perspective on honour, one that put the emphasis not on nature, or blood/heart, but upon nurture, that is, the importance of learning and virtue (James 1978: 310-315). Thus, James Cleland in his Institution of a Young Noble Man (1627) refers to the evidence that "betweene our birth and burial, wee are over-runne by our betters, and of necessitie must needes confesse that some excell \& are more noble then others" (ib. 3), in order to introduce a distinction between "Natural Nobilitie" (honour by nature, blood, or lineage) and "Personal or Inherent Nobilitie" (honour by nurture: acquired through virtue, prowess, and learning) (ib. 3-6).

According to Giuseppina Restivo, in her acute Lotmanian analysis of Shakespeare, Machiavelli and Montaigne, "the syntagmatic code of the Renaissance overturns the preceding point of view" (Restivo 1996: 45). Following Lotman, she concludes that in this period "no longer split between actual facts and a transcendent symbolic meaning, reality is now referred upon one central structure, common to all” (ib.). This emergent, syntagmatic, concept of honour is, as we have seen, relational, and this implies that it rejects the subversive individualism of the medieval man of honour, who did whatever his conscience told him that was right, unaware of axiological, intellectual, or political constraints, according to a principle of conduct that resided somewhere else. Consequently, this syntagmatic code also emphasizes the virtue of conformism, rejects the private, uncontrolled use of violence of the previous residual medieval sense of honour, and, as well as being centralized in the figures of the monarch and God, eventually introduces a concern with learning (which replaces medieval 'prowesse') and success (instead of steadfastness). Thomas 
A Lotmanian Approach to the Ideological Function of Honour in Early Modern English Texts

Elyot, who was writing in order to sustain this emergent concept of honour, was also aware of how difficult it was going to be to get rid of the residual paradigmatic one; in his Boke Named the Gouernour (1531) he explains:

Severitie, Magnanimitie, Constance, Honour, Sapience, Continence. These qualities [...] do expresse or sette out the figure of very nobilitie; whiche in the higher astate it is contained, the more excellent is the vertue in estimation. (1531: 95)

The man of honour of the early modern period had to cope with an old, medieval, syntagmatic code, and with the tensions of a new, paradigmatic, one. Indeed, as I suggested above, there existed a residual paradigmatic sense of honour which still emphasized the importance of steadfastness and prowess, and which insisted on the preeminence of blood and lineage, whereas the emergent syntagmatic one introduced success, "Sapience" or learning, "Continence" or abstaining from behaving in an uncontrolled way, and political allegiance to a centralized state. That these two notions of honour were confronting each other, and this constituted the dominant cultural form in the sixteenth century, can be perceived in Elyot's uncomfortable balance of syntagmatic and paradigmatic versions of honour: for him "glorie [is] whiche euery noble hart desireth" (Elyot 1531: 238), and magnanimity is "an excellencie of mynde concernynge thynges of great importaunce or estimation, doynge all thynge that is vertuous for the achieuinge of honour." (Ib. 239) Here, Elyot seems to be recurring to an earlier version of honour, one which seems to trust the individual aspiration to his own form of virtue.

A strong advocate of early modern honour, the Elizabethan essayist and polyglot Robert Ashley, in his treatise Of Honour (1600), strongly influenced by Spanish and Italian writings on this subject, emphasizes this new relational and centralized - moralized in some way - role of honour, which he sees, in a typically early modern, syntagmatic, fashion, as the cement of the community:

by honour are Cities kept, famelies preserved, the society of men quietly and peaceably continued, the common wealth defended [without honour] Magnanimitie will perish, fortitude, moderacion, and decencie will decay, the observaunce of lawes and lawes themselves wilbe neglected, offyces of honour despised, magistrates contemned, discordes arise amongst Cittizens, and every one dare to do each foule and wicked deed. (Ashley 1947: 30) 
LÓPEZ-PELÁEZ CASELLAS

However, Ashley's relational approach to honour is - following Aristotle - aristocratic, or elitist, as it can be clearly perceived in his distinction between glory and honour:

yt ys of glorie when any mans name ys magnified amongst many and ys much spoken of in euery bodyes mouth as renowned and very rare. Honour on the contrary being content with the ample approbacion of the better sort. (Ib. 36)

The new early modern concern with learning, which as we saw replaced medieval emphasis on prowess, and according to Mervyn James was introduced by the late sixteenth century grammar school and the advent of Puritanism in England (1978: 338-339), finds its place in Ashley's Elizabethan approach to the various ways to attain honour, in which the typically medieval values of violence or assertiveness can no longer be found:

vertue, excellencie of mind, witt, learning, knowledge of many thinges, experience, age, riches, nobilitie, freindes, Clyentes, favour and all the rest which are termed goodes either of the mind, of the bodie, or of fortune. (Ib. 55)

But it is in this text where we can most clearly find how Ashley's sense of honour has internalized the Lotmanian syntagmatic, relational, features of the sixteenth and seventeenth centuries, by emphasizing how honour has ceased to be the realm of the single autonomous individual and now completely depends on others:

Therefore neither to be praysed, nor to be reverenced, nor to be esteemed ys for yt self to be desired; but that we may behold the Testymonie which good men and wise haue geven of our vertue and be delighted therwith, as hauing not so much confidence in our selves herein as in the iudgement of others. (Ib. 59)

Almost thirty years later, James Cleland insisted on this same relational characteristic of honour in his Institution of a Young Noble Man (1627): 
A Lotmanian Approach to the Ideological Function of Honour in Early Modern English Texts

it is not in his hand who is honoured, but in the hearts and opinion of other men, who either haue seene his merits, or heard of his renowne, and good reputation, albeit they be distant manie thousand miles from him (Cleland 1627: 179).

Recourse to private violence was, as we saw, one of the major changes that honour had to undergo in order to adapt to the new code of culture characteristic of the early modern period. No longer legitimized to provide moral reinforcement to a politics of violence (James 1978: 309), honour starts now to actively discredit the aggressive behaviour traditionally associated with medieval honour. Thomas Elyot's writing proves to be especially effective in attacking the uncontrollably violent medieval man of honour:

(F)or who, beholdynge a man in estimation of nobilitie and wisedom by furie chaunged in to an horrible figure, his face infarced with rancour, his mouthe foule and imbosed, his eien wyde starynge and sparklynge like fire, nat spakyng, but as a wylde bulle, rorying and brayienge out wordes despitefull and venomous; forgetynge his astate or condition, forgeting lernyng, ye forgetynge all reason, wyll nat haue suche a passion in extreme detestation? (Elyot 1531: 136)

Elyot even disqualifies an excessive love of honour by defining it as - following Cicero - a pernicious vice, which he identifies with ambition: "The more higher of courage that a man is, and desirous of glorie, the soner is he meued to do thinges agayne right" (ib. 245). Likewise, Lodowycke Bryskett, in A Discourse of Civill Life (1606, probably written two decades earlier) also criticizes this same attitude: ambition has ceased to be a distinguishing feature of a chivalrous attitude, to be condemned as an indignity, and it is disqualified for lacking reason and unleashing violence, features that had never been paid any attention to by the anti-intellectual tradition of medieval honour:

the disordinate appetites, unreasonable anger, ambitions, greedy desires of wealth, of honour, wanton lusts of the flesh, and such other affections spoken of before, which have their naturall rootes in those two baser parts of the soule devoyde of reason (Bryskett 1606: 89). 
LÓPEZ-PELÁEZ CASELLAS

However, Bryskett's text also introduces a considerable amount of ambiguity, as he finds himself in the middle of the epistemological clash between emergent (syntagmatic) and residual (paradigmatic) types of honour; so he simultaneously criticizes, as we have seen, "unreasonable anger" while he advises to revenge when given the lie:

he that receiveth it, standeth so charged in his honor and reputation, that he cannot disburden himselfe of that imputation, but by striking of him that hath so given it, or by chalenging him the combat (ib. 50).

But, also by Bryskett: "Duellum is a foolish custom and wicked act" (ib. 51). This contradiction has been perceived by some scholars, like Chris Boswell, who claims that Bryskett's Discovrse is at times self-contradictory on the subject of reprisal, since "contrary to what he claims about the dishonour and wickedness of retaliation, he also argues that it is imperative to be aggressively proactive in defence of one's good name" (Boswell 2003: 42). Furthermore, this conflict within Bryskett's text can be also found in his emphasis on nominalism, or in the contradictory connections that he appears to perceive between physical appearance and virtue (Boswell 2003: 27, 30).

A centralized sense of honour follows, as we saw, from a syntagmatic approach to reality, which is no longer split between facts and transcendence, and consequently James Cleland makes explicit, already in the Stuart period, the now obvious subordination of honour to the king, who, as a typical feature of providentialist belief, can dishonour his subjects at will:

If wee should suffer our selves to be dishonoured by anie whosoeuer, except it bee by his Maiestie, who maie dispose of our liues at his pleasure, our state were miserable (Cleland 1627: 235).

Indeed, service to the prince is for Cleland as important as honour itself, and to the service of the monarch should be subordinated that residual notion, prowess, now defined not as a quality of the individual in his personal quest for glory but as "an habitud of the minde, wherby a man is resolved to hazard himselfe unto al perils \& paines for the good of his Prince, Countrie, and for his owne honour, aduisedlie" (ib. 230). By the beginning of the eighteenth century, the total submission of the reputation of a knight to the general welfare, symbolized by the service to the king and an orderly life, had been completely accepted by 
A Lotmanian Approach to the Ideological Function of Honour in Early Modern English Texts

the aristocracy, who after the Restoration had abandoned all thoughts of dissident honour. Thus, the 1711 epitaph of Sir Robert Atkyns of Gloucestershire, who had been knighted by Charles II in 1663, manifests the already dominant culture of honour, with no mention of glory, prowess or steadfastness: "He was always loyal to his Prince, loving to his wife, faithful to his friends, charitable to the poor, kind and courteous to his neighbours, just to all, sober and serious in his conversation and a peacemaker to the uttermost of his powers." (Simmons 1978: 63)

Thomas Hobbes had already warned against the artificial nature of (symbolic) honour, which he considered but a consequence of power, and a relative (and relational), not absolute, value within a centralized political system. In the tenth chapter of his Leviathan (1651) ("Of Power, Worth, Dignity, Honour, and Worthiness") Hobbes explains:

The value, or worth, of a man is, as of all other things, his price; that is to say, so much as would be given for the use of his power; and therefore is not absolute, but a thing dependent on the need and judgment of another. (Hobbes 1999: $\mathrm{X}$, 54-55).

Just like he distinguishes between natural and instrumental powers (1999: X, 53), Hobbes also differentiates between 'natural ways of honouring' and 'other honours' (that is, those derived from the Commonwealth, or institutionalized power). But whatever their origin, function or essence, all honour, reputation or dignity is never an absolute but a relative thing and, what is even of more relevance, the actual content of the action, its relation with a meaning that may be ascribed to it, is of no relevance, as honour has no longer any autonomous entity and now depends entirely on the power of the monarch:

Nor does it alter the case of honour whether an action (so it be great and difficult, and consequently a sign of much power) be just or unjust: for honour consisteth only in the opinion of power (Hobbes 1999: 58). 
LÓPEZ-PELÁEZ CASELLAS

\title{
Conclusion
}

The concept of honour is one central concern of early modern essayists and, as some scholars have already shown, of much early modern poetry and drama. ${ }^{8}$ In the previous pages I have attempted to provide a succinct examination of the evolution of the notion of honour as presented by sixteenth and seventeenth century texts dealing with moral and political issues, and more specifically with honour as an axiological and ideological concept. That there is a conflict between two versions of honour had already been suggested by some authors (see for example Anita Pacheco's Shakespeare and the Contradictions of Honour, Pacheco 1990): as I have already explained, the early modern subject had to deal with a medieval code of honour which coexisted side by side with a new, early modern, one, which produced contradiction and conflict. But it is only thorough Yuri Lotman's semiotic model explaining what he called the 'typology of cultures,' mediated by Raymond Williams' perception of the residual, emergent and dominant forms of culture, that we can account for the radical transformation that honour experiences in the transition between the Middle Ages and the early modern period. Much of the conflictive nature of the honour of the seventeenth century can only be apprehended by making reference to this model, which accounts for the decline of oaths and promises, lineage and prowess, steadfastness and independence, and explains the rise of submission and centralization, subordination to the monarch and relativity of certain values, and the notion of honour as the external, royal 'reward of virtue.'

\author{
Jesús López-Peláez Casellas \\ jlopez@ujaen.es \\ Departamento de Filología Inglesa, D2-245 \\ Universidad de Jaén \\ 23071 Jaén \\ ESPAÑA
}

8 See for example the seminal works by Watson (1960), Siegel (1964), or Council (1973). More recently, see Alvis 1990, Pacheco 1990, Reta 1999, Fernie 2002, Zaidi 2003 and López-Peláez Castellas 1992, 1998, 2003, 2004, 2009. 
A Lotmanian Approach to the Ideological Function of Honour in Early Modern English Texts

\section{References}

Alvis, J. 1990. Shakespeare's Understanding of Honour. Durham, NC: Carolina Academic Press.

Annas, J. 1981. An Introduction to Plato's Republic. Oxford: Oxford University Press. Aristotle. 1970. Ethica Nichomachea [I. Bywater, ed.]. Oxford: Classical Texts.

Aristotle. 1971. Eudemian Ethics [H. Rackham, ed.]. London: Loeb Classical Library.

Aristotle. 1984. The Complete Works [J. Barnes, ed.]. Princeton: Princeton University Press.

Ashley, R. 1947 [1600]. Of honour [V. Heltzel, ed.]. San Marino, CA: The Huntington Library.

Aurelius, M. 1979 Ta eis heauton. M. Aurelius. Ad se ipsum libri duodecim [J. Dalfen, ed.]. Leipzig: Teubner.

Aurelius, M. 1985. Meditaciones. Madrid: Alianza Editorial.

Book of Saint Albans. 1486 [1518]. London. - English Early Books Online.

Boswell, Ch. The Culture and Rhetoric of the Answer-poem, 1485-1625. Unpub. PhD Thesis. The University of Leeds.

Bryskett, L. 1970 [1606]. A Discourse of Civill Life [T. E. Wright, ed.]. San Fernando, CA: San Fernando Valley State College.

Cairns, D. L. 1993. Aidōs. The Psychology and Ethics of Honour and Shame in Ancient Greek Literature. Oxford: Clarendon Press.

Chew, A. 1988. Stoicism in Renaissance English Literature. An Introduction. New York: Peter Lang.

Cicero. 1976. De finibus bonorum et malorum [N. Marinone, ed.]. Torino.

Cicero. 1989. Sobre los deberes [J. Guillén, transl.]. Madrid: Tecnos.

Cleland, J. 1948 [1627]. The Institution of a Young Noble Man. New York: Scholars Facsimiles \& Reprints.

Council, N. 1973. When Honour's at the Stake. London: Allen \& Unwin.

Elyot, Th. 1907 [1531]. The Boke Named the Gouernour London \& New York: Everyman.

Epictetus.2012.TheEnchiridion. Trans.E. Carter. - http://classics.mit.edu/Epictetus/ epicench.html. (15.10.2012)

Fernie, E. 2002. Shame in Shakespeare. London \& New York: Routledge.

Guevara, A. 1557 [1521]. The Dial of Princes [Sir Th. North, transl.]. London.

Hill, Ch. 1965. Intellectual Origins of the English Revolution. Oxford: Clarendon.

Hobbes, Th. 1999 [1651]. Leviathan, or the Matter, Forme, and Power of a Commonwealth Ecclesiasticall and Civil. Hamilton: McMaster University Archive of the History of Economic Thought.

Irwin, T.H. 1985. Aristotle: Nichomachean Ethics. Indianapolis: Indiana University Press.

Jaeger, W. 1945. Paideia. Los ideales de la cultura griega. Madrid: Fondo de Cultura Económica.

James, M. 1978. English Politics and the Concept of Honour. - Society, Politics and Culture. Cambridge: Cambridge University Press, 308-415. 
LÓPEZ-PELÁEZ CASELLAS

López-Peláez Casellas, J. 1992. Saint Augustine and the Renaissance Concept of Honour. - Ma L. Dañobeitia, ed., Proceedings of the III Conference of the Spanish Society for English Renaissance Studies. Granada: Universidad de Granada, 139-149.

López-Peláez Casellas, J. 1998. 'Ocular Proofs': Análisis comparado de los formantes 'pañuelo' y 'daga' en Othello y El médico de su honra. - Studia Neophilologica, 70, 187-196.

López-Peláez Casellas, J. 2003. Two Different Approaches to the Coriolanus Theme: A Preliminary Study of Shakespeare's Coriolanus and Calderón's Las armas de la hermosura. - Interlitteraria, 8, 213-227.

López-Peláez Casellas, J. 2004. 'And dressed myself in such humility': Honour and Disguising in Henry IV. - J. López-Peláez, D. Malcolm, P. Sánchez, eds., Masquerades. Disguise in Literature in English from the Middle Ages to the Present. Gdansk: Gdansk University Press, 38-54.

López-Peláez Casellas, J. 2009. Honourable Murderers. El concepto del honor en Othello de Shakespeare y en los dramas de honor de Calderón. Frankfurt am Main: Peter Lang.

Lotman, J. M. 1978. On the Semiotic Mechanism of Culture. - New Literary History, 9, 2, 211-232.

Lotman, J. M. 1979. El problema del signo y del sistema sígnico en la tipología de la cultura anterior al siglo XX. - J. Lozano, ed., Semiótica de la cultura. Madrid: Cátedra, 41-66.

Lotman, J. M. 1994. The Text within the Text. - PMLA, 109, 3, 377-384.

Lotman, J. M. 1996-2000. La semiosfera [3 vols]. Madrid: Cátedra/Universitat de València.

Lotman, J. M.Universe of the Mind. A Semiotic Theory of Culture. 2001. London and New York: Tauris.

Lull, R. 1926 [1276]. The Book of the Ordre of Chivalry. Ed. A. T. Byles. London: Early English Text Society.

Markham, F. 1625. The Booke of Honour, or, Five Decades of Epistles of Honour. London. Markham, G. 1624. Honour in his Perfection. London.

Milles, Th. 1610. The Catalogue of Honour. London: English Early Books Online.

Norden, J. 1597. The Mirror of Honor. London.

Oxford English Dictionary Online. - www.oed.com (27/11/2012)

Plutarch. Parallel Lives. - http://penelope.uchicago.edu/Thayer/E/Roman/Texts/ Plutarch/Lives/home.html (10/09/2012)

Pacheco, A. 1990. Shakespeare and the Contradictions of Honour. Unpub. PhD Thesis. Microfilm edition. York: University of York.

Restivo, G. 1996. Shakespeare between Machiavelli and Montaigne: An Exploration Through Lotman's Codes. - Interlitteraria, 1, 41-62.

Reta, T. T. 1999. 'Vows to the blackest devil': Hamlet and the Evolving Code of Honor in Early Modern England. - Renaissance Quarterly, 52, 4, 1070-17.

Rodríguez, J. C. 1990. Teoría e historia de la producción ideológica. Las primeras literaturas burguesas. Madrid: Akal.

Romei, H. 1598. The Courtier's Academie. London. 
A Lotmanian Approach to the Ideological Function of Honour in Early Modern English Texts

Schneider, B. R. Shakespeare's Morals. - http://www.stoics.com/ (15.12.2012)

Segar, W. 1590. The Booke of Honor and Armes. London.

Seneca, L. A. 1917-1925. Moral Epistles. Trans. R. M. Gummere. Cambridge, MA: The Loeb Classical Library, Harvard University Press.

SEP = Stanford Encyclopedia of Philosophy. - http://plato.stanford.edu/entries/ analogy-medieval/ (28.09.2012).

Serpieri, A. 1991. Reading the signs: towards a semiotics of Shakespearean drama. J. Drakakis, ed., Alternative Shakespeares. London \& New York: Routledge, 119143.

Siegel, P. N. 1964. Shakespeare and the Neo-Chivalric Cult of Honour. - The Centennial Review, 8, 1, 39-70.

Simmons, J. 1978. English County Historians. Wakefield: EP Publishing.

Watson, Curtis B. 1960. Shakespeare and the Renaissance Concept of Honour. Princeton: Princeton University Press.

Williams, R. 1977. Marxism and Literature. Oxford: Oxford UP.

Williams, R. 1980. Problems in Materialism and Culture. London \& New York: Verso.

Zaidi, A. 2003. Coriolanus and the Paradox of Rome in Shakespeare and Calderón. Hispanófila, 137, 1-17. 